\title{
4-Hydroxyestradiol Induces $\gamma$-H2AX in the Presence of an Inhibitor of Catechol-O-methyltransferase in Human Breast Cancer MCF-7 Cells
}

\author{
Shunsuke Yamazaki ${ }^{1}$, Hiroyuki Sakakibara ${ }^{2}$, Hitomi Takemura ${ }^{3}$ and Kayoko Shimoi ${ }^{4,5}$ \\ ${ }^{1}$ Graduate School of Nutritional and Environmental Sciences, University of Shizuoka, Shizuoka, Japan \\ ${ }^{2}$ Faculty of Agriculture, University of Miyazaki, Miyazaki, Japan \\ ${ }^{3}$ Department of Home Economics, Aichi Gakusen University, Aichi, Japan \\ ${ }^{4}$ Global COE Program, University of Shizuoka, Shizuoka, Japan \\ ${ }^{5}$ Graduate School of Integrated Pharmaceutical and Nutritional Sciences, University of Shizuoka, Shizuoka, Japan
}

(Received April 25, 2012; Revised May 15, 2012; Accepted May 17, 2012)

$17 \beta$-Estradiol $\left(E_{2}\right)$ is crucial for various physiological functions, such as in the development of the uterus and the mammary gland. However, prolonged exposure to $E_{2}$ is a risk factor for breast cancer. $E_{2}$ is metabolized to carcinogenic 4-hydroxyestradiol $\left(4-\mathrm{OHE}_{2}\right)$ and non-carcinogenic 2-hydroxyestradiol $\left(2-\mathrm{OHE}_{2}\right)$ by CYP1A1 and CYP1B1 in the breast tissue, respectively. These two catechol estrogens are converted to methylated metabolites by catechol$O$-methyltransferase (COMT). 4-OHE 2 has been reported to be further oxidized to quinone intermediates which react with purine bases in DNA to form depurinating adducts, which generate highly mutagenic apurinic (AP) sites. Recently, phosphorylation of histone H2AX $(\gamma-\mathrm{H} 2 \mathrm{AX})$ has emerged as a sensitive marker for not only DNA doublestrand breaks but also various types of DNA damage. 4-OHE $\mathrm{H}_{2}$-induced $\gamma$-H2AX in MCF-7 cells has never been reported yet. In this study, we investigated whether 4- $\mathrm{OHE}_{2}$ induces $\gamma-\mathrm{H} 2 \mathrm{AX}$ in response to DNA damage in the presence or absence of Ro 41-0960, an inhibitor of COMT, in human breast cancer MCF-7 cells. AP sites and $\gamma-\mathrm{H} 2 \mathrm{AX}$ were induced 1-2 $\mathrm{h}$ after treatment with $4-\mathrm{OHE}_{2}$ and Ro 41-0960. The generation of intracellular reactive oxygen species (ROS) was also observed, as determined by $2^{\prime}-7^{\prime}$ dichlorodihydrofluorescein diacetate fluorescence. By comparison, 2-OHE 2 and Ro 41-0960 had no effect on AP sites, $\gamma$-H2AX or the generation of ROS. KU-55933, an inhibitor of ataxia telangiectasia mutated (ATM), decreased the formation of $\gamma-\mathrm{H} 2 \mathrm{AX}$ in conjunction with $4-\mathrm{OHE}_{2}$ and Ro 41-0960. These results demonstrate that $4-\mathrm{OHE}_{2}$, in the presence of Ro 41-0960, induces ATM-dependent $\gamma$ H2AX in MCF-7 cells.

Key words: 4-hydroxyestradiol, $\gamma$-H2AX, catechol-Omethyltransferase, apurinic sites

\section{Introduction}

Breast cancer is the most common cancer in women worldwide (1). An increased risk has been associated with genetic alterations, such as in breast cancer susceptibility gene $1(B R C A 1), B R C A 2$, and in tumor protein 53 (TP53) $(2,3)$. Other risk factors include the prolonged exposure of estrogens due to situations such as an early onset of menstruation, late menopause, or the use of hormone replacement therapy (4-6). Estrogens, especially in postmenopausal women, are well known to play a role in breast cancer etiology $(1,7-10)$. Estrogens are not only mitogenic, but also genotoxic agents. The most biologically active estrogen in breast tissue is $17 \beta$-estradiol $\left(\mathrm{E}_{2}\right) . \mathrm{E}_{2}$ is metabolized into the catechol estrogens, non-carcinogenic 2-hydroxyestradiol $\left(2-\mathrm{OHE}_{2}\right)$ and carcinogenic 4-hydroxyestradiol (4-OHE $)_{2}$, by cytochrome P450 (CYP) family proteins, especially CYP1A1 and CYP1B 1 in the breast tissue, respectively (11). 2- $\mathrm{OHE}_{2}$ and $4-\mathrm{OHE}_{2}$ are rapidly methylated by catechol- $O$-methyl-transferase (COMT) to 2-methoxyestradiol $\left(2-\mathrm{MeOE}_{2}\right)$ and 4-methoxyestradiol $\left(4-\mathrm{MeOE}_{2}\right) ; 2-\mathrm{MeOE}_{2}$ is known to be anti-carcinogenic (12). These two catechol estrogens and their methylated metabolites are generally inactivated by conjugating reactions, such as glucuronidation and sulfation. However, it has been reported that higher levels of CYP1B1 expression and low levels of COMT expression were associated with increased breast cancer risk (13). $4-\mathrm{OHE}_{2}$ has been reported to be further oxidized to quinones, such as estradiol-3,4-quinone $\left(\mathrm{E}_{2}-3,4-\mathrm{Q}\right)$, and accompanied by the generation of reactive oxygen species (ROS) (14). Female SENCAR (SENsitive to CARcinogenesis) mice or ACI rats treated with $\mathrm{E}_{2}-3,4-\mathrm{Q}$ show the formation of $4-\mathrm{OHE}_{2}-1-\mathrm{N}^{3} \mathrm{Ade}$ and $4-\mathrm{OHE}_{2}-1-\mathrm{N}^{7} \mathrm{Gua}$

${ }^{5}$ Correspondence to: Kayoko Shimoi, Graduate School of Integrated Pharmaceutical and Nutritional Sciences, University of Shizuoka, 52-1 Yada, Suruga-ku, Shizuoka 422-8526, Japan. Tel/Fax: +8154-264-5787, E-mail: shimoi@u-shizuoka-ken.ac.jp

doi: $10.3123 /$ jemsge. 34.129 
adducts in the mouse skin (15) or rat mammary gland (16), respectively. In the mouse skin, $\mathrm{E}_{2}-3,4-\mathrm{Q}$ induces mainly A-to-G mutations in the reporter $H$-Ras gene, presumably because the $\mathrm{N}^{3}$ Ade adducts depurinate rapidly, leading to premutagenic apurinic (AP) sites $(1,9,15,17)$. On the other hand, the $\mathrm{N}^{7} \mathrm{Gua}$ adducts depurinate relatively slowly, allowing accurate DNA repair $(15,18-20)$. These results suggest that $E_{2}-3,4-Q$ may be the major carcinogenic metabolite of estrogens. Recently, phosphorylation of histone H2AX (termed $\gamma$ $\mathrm{H} 2 \mathrm{AX}$ when phosphorylated) was identified as an early event after induction of double-strand breaks (DSBs) by ionizing radiation or radiomimetic drugs, which generate ROS (21). H2AX protein is phosphorylated at serine residue 139 , and the kinases responsible for $\gamma$ - $\mathrm{H} 2 \mathrm{AX}$ have been studied in detail. It is now clear that members of the phosphatidylinositol 3-kinase (PI3K) family, including ATM (ataxia telangiectasia mutated), ATR (ATM and Rad3-related), and DNA-PK (DNA-dependent protein kinases) are involved in the induction of $\gamma$ H2AX (22-26). Williamson and Lees-Miller have shown that $\mathrm{E}_{2}$ also induces the formation of $\gamma-\mathrm{H} 2 \mathrm{AX}$ and foci over 6-24 h in human breast cancer MCF-7 cells (27). It was suggested that $\mathrm{E}_{2}$-induced DSBs are mediated by progression through $\mathrm{S}$ phase (27). However, there is no report on the induction of $\gamma-\mathrm{H} 2 \mathrm{AX}$ by catechol estrogens in DNA damage. Here, we investigated whether 4- $\mathrm{OHE}_{2}$ induces $\gamma$-H2AX in response to DNA damage such as AP sites in the presence or absence of a COMT inhibitor in MCF-7 cells.

\section{Materials and Methods}

Chemical and reagents: 2- $-\mathrm{OHE}_{2}, 4-\mathrm{OHE}_{2}$, Ro 41-0960 (COMT inhibitor) were purchased from the Sigma Chemical Co (St. Louis, MO, USA) and prepared as $10 \mathrm{mM}$ stock solutions in dimethyl sulfoxide (DMSO for $2-\mathrm{OHE}_{2}$ and $4-\mathrm{OHE}_{2}$ ) or $99 \%$ ethanol (for Ro 41-0960). 2'-7'-Dichlorodihydrofluorescein diacetate (DCFH-DA) was also purchased from Sigma. The ATM inhibitor 2-morpholin-4-yl-6-thianthren-1-ylpyran-4-one (KU-55933) was supplied from Chemdea (Ridgewood, NJ, USA) and prepared as a $10 \mathrm{mM}$ stock solution in DMSO. All the other chemicals and reagents were obtained from Wako Pure Chemical Industries Ltd. (Osaka, Japan).

Cell lines: MCF-7 human breast cancer cells were obtained from the American Type Culture Collection (Manassas, VA, USA) and maintained in Dulbecco's modified Eagle's medium (DMEM; Invitrogen, Carlsbad, CA, USA) supplemented with $10 \%$ (vol/vol) fetal bovine serum (FBS, Invitrogen, Logan, UT), 50 $\mathrm{U} / \mathrm{mL}$ penicillin and $50 \mu \mathrm{g} / \mathrm{ml}$ streptomycin (Invitrogen) at $37^{\circ} \mathrm{C}$ under a humidified atmosphere of $5 \%$ $\mathrm{CO}_{2}$. Prior to the addition of catechol estrogens, cells were cultured in phenol red-free DMEM (Invitrogen) supplemented with $10 \%$ (vol/vol) charcoal/dextrantreated FBS (Invitrogen), $50 \mathrm{U} / \mathrm{mL}$ penicillin and 50 $\mu \mathrm{g} / \mathrm{mL}$ streptomycin (Invitrogen).

Cell culture and treatment: MCF-7 cells $\left(1 \times 10^{4}\right.$ cells) were seeded into $100 \mathrm{~mm} \phi$ petri dishes and cultured in estrogen-containing medium for 3 days. The medium was changed to estrogen-free medium, and the cells were grown for another 2 days. The cells were then treated with $3 \mu \mathrm{M}$ Ro 41-0960 (28), $10 \mu \mathrm{M}$ KU-55933 (29), $30 \mu \mathrm{M} 2-\mathrm{OHE}_{2}$ and/or $30 \mu \mathrm{M} 4-\mathrm{OHE}_{2}$, as described in each section of the results and the corresponding figure legends. DMSO $(0.1 \%$ of final volume $)$ was used as a vehicle control in the experiment.

SDS-PAGE and western blotting analysis: After treatment, cells were washed with PBS and then lysed at $4^{\circ} \mathrm{C}$ for 5 min using a cell lysis buffer (Cell Signaling Technology Inc., MA, USA). The protein concentration was determined using a BCA kit (Pierce Biotechnology Inc., USA). Protein samples $(10 \mu \mathrm{g})$ were separated on $12.5 \%$ SDS-PAGE gels, and transferred to nitrocellulose membranes (GE Healthcare, NJ, USA) at $144 \mathrm{~mA}$ for $2 \mathrm{~h}$. Blots were blocked with Blocking Ace buffer (UK-B80; Dainippon Sumitomo Pharma, Osaka, Japan) for $3 \mathrm{~h}$ at room temperature. The membranes were washed three times for 5 min each with PBST (PBS with $0.1 \%$ Tween-20). The membranes were then incubated with primary antibodies against phospho-H2AX (1:500 dilution, DAM1546024; Upstate Biotechnology, USA), Histone H2AX (1:500 dilution, 31783; Upstate Biotechnology, USA) or actin antibody (1-19, 1: 500 dilution, SC-1616; Santa Cruz Biotechnology) at $4{ }^{\circ} \mathrm{C}$ overnight. Membranes were washed three times in PBST and then incubated for $2 \mathrm{~h}$ with the appropriate rabbit or goat HRP-conjugated secondary antibody (rabbit IgG, 1:2000 dilution, 7074; Cell signaling; goat IgG, 1:2000 dilution, SC-2350; Santa Cruz Biotechnology). The blots were washed again three times in PBST and protein was detected with the ECL Plus Western Blotting Detection System (Amersham Bioscience, UK), after a $5 \mathrm{~min}$ incubation. The bands were quantified with CS Analyzer/Cool Saver (ATTO Co., Japan).

Determination of intracellular ROS: Intracellular ROS production was measured by incubating the cells with the fluorescent probe DCFH-DA. Briefly, MCF-7 breast cancer cells were pretreated with or without a COMT inhibitor (Ro 41-0960) for $1 \mathrm{~h}$, and then exposed to $30 \mu \mathrm{M} 2-\mathrm{OHE}_{2}$ or $30 \mu \mathrm{M} 4-\mathrm{OHE}_{2}$ or DMSO (vehicle control) for $0-2 \mathrm{~h}$. Cells were then incubated with PBS buffer containing $5 \mu \mathrm{M}$ DCFH-DA for $30 \mathrm{~min}$ at $37^{\circ} \mathrm{C}$. DCFH-DA was then removed and the cells washed twice with fresh PBS to remove excess DCFH-DA. Cells treated with $100 \mu \mathrm{M} \mathrm{H}_{2} \mathrm{O}_{2}$ were used as a positive control and non-DCFH-DA-loaded cells were used as a negative control. At the end of the incubation, DCFH fluorescence from each well was measured at an emission 
wavelength of $530 \mathrm{~nm}$ and an excitation wavelength of $485 \mathrm{~nm}$ using a Varioskan Flash Multimode Reader (Thermo Fisher Scientific, Inc, MA, USA). The data are presented as DCFH fluorescence (fold increase vs control), which corresponds to the increase in fluorescence associated with the sample cells compared with that of the untreated cells.

AP sites assay: MCF-7 breast cancer cells were pretreated with or without a COMT inhibitor (Ro 41-0960) for $1 \mathrm{~h}$, and then exposed to $30 \mu \mathrm{M} 2-\mathrm{OHE}_{2}$ or $30 \mu \mathrm{M} 4-\mathrm{OHE}_{2}$ or DMSO (vehicle control) for $0-2 \mathrm{~h}$. After that, the treated cells were collected and rinsed with phosphate buffer (PBS) (pH 7.4) twice. DNA was isolated from the cells by Getpure DNA kit cell, tissue (Dojindo Molecular Technologies, Kumamoto, Japan), and then AP sites lesions in the genomic DNA were quantified using a DNA damage quantification kit (Dojindo Molecular Technologies, Kumamoto, Japan) according to the protocol commercially provided.

Cell proliferation assay: The Cell Counting Kit- 8 (CCK-8) (Dojindo Molecular Technologies) was used as a qualitative index of cell viability. In brief, MCF-7 cells were seeded into 96-well plates $\left(1 \times 10^{4}\right.$ cells $)$ and cultured in estrogen-containing medium for 3 days. The medium was changed to estrogen-free medium and the cells were grown for another 2 days. Cells were then treated with or without a COMT inhibitor (Ro 41-0960) for $1 \mathrm{~h}$ before exposure to $30 \mu \mathrm{M} 2-\mathrm{OHE}_{2}, 30 \mu \mathrm{M}$ $4-\mathrm{OHE}_{2}$ or DMSO (vehicle control) for $0,6,8$ or $12 \mathrm{~h}$. After treatment, the CCK-8 assay was carried out according to the manufacturer's instructions. The optical density of each well was measured using a Varioskan Flash Multimode Reader with a test wavelength of 450 nm.

Statistical analysis: Values are indicated as the mean \pm standard deviation (S.D.). Statistical analyses were performed using Tukey test with the software program Pharmaco Analyst I, II (Hakuhousha Co., Tokyo, Japan). Different alphabetical superscripts on the top of each column indicate statistically significant differences at $p<0.05(n=5)$.

\section{Results}

Induction of $\gamma-\mathrm{H} 2 \mathrm{AX}$ by $2-\mathrm{OHE}_{2}$ or $4-\mathrm{OHE}_{2}$ in the presence or absence of a COMT inhibitor: The potential induction of $\gamma-\mathrm{H} 2 \mathrm{AX}$ by $2-\mathrm{OHE}_{2}$ or $4-\mathrm{OHE}_{2}$ was first tested using MCF-7 cells. MCF-7 cells were cultured in estrogen-containing medium for 3 days, and then switched to estrogen-free medium for another 2 days prior to treatment. Cells were treated with $3 \mu \mathrm{M}$ COMT inhibitor, Ro 41-0960 for $1 \mathrm{~h}$, prior to exposure to $2-\mathrm{OHE}_{2}, 4-\mathrm{OHE}_{2}$ or DMSO (vehicle control) for 0$2 \mathrm{~h}$. As shown in Fig. $1 \mathrm{~A}$ and $\mathrm{B}, 2-\mathrm{OHE}_{2}$ did not induce $\gamma$-H2AX in the presence or absence of Ro 41-0960. $4-\mathrm{OHE}_{2}$ alone also did not induce $\gamma-\mathrm{H} 2 \mathrm{AX}$ (Fig. 1C).
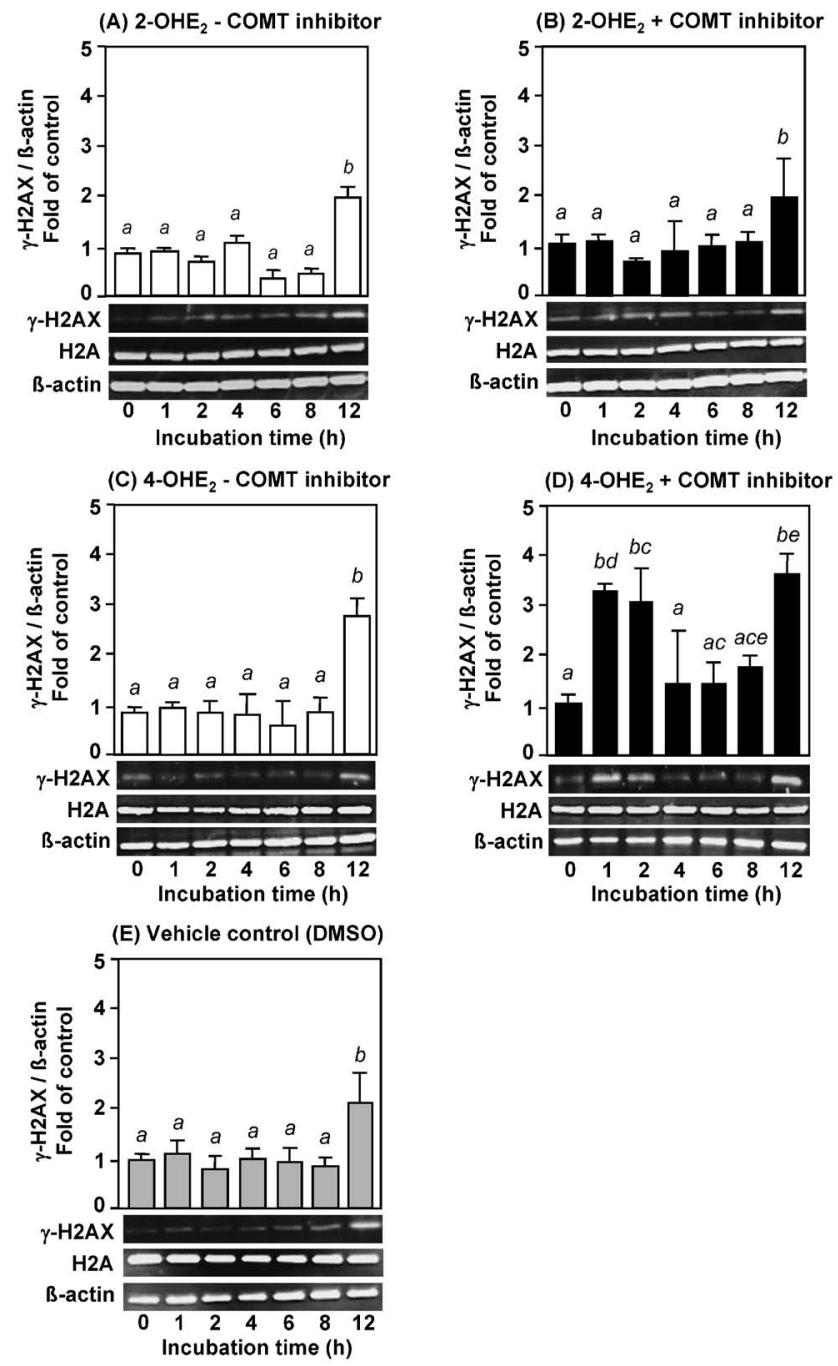

Fig. 1. Induction of $\gamma-\mathrm{H} 2 \mathrm{AX}$ in $\mathrm{MCF}-7$ cells treated with $2-\mathrm{OHE}_{2}$ or 4-OHE 2 , in the presence or absence of a COMT inhibitor. MCF-7 human breast cancer cells were pretreated with (B and D) or without (A, $\mathrm{C}$ and E) COMT inhibitor (3 $\mu \mathrm{M}$ Ro 41-0960) for $1 \mathrm{~h}$, and then exposed to $30 \mu \mathrm{M} 2-\mathrm{OHE}_{2}$ (A and B), 4-OHE $(\mathrm{C}$ and D) or DMSO (vehicle control (E)) for 0-12 h. Values indicate the mean \pm S.D. $(n=5)$. Different alphabetical superscripts on the top of each column indicate statistically significant differences at $p<0.05$ as evaluated by the Tukey test.

However, 4- $\mathrm{OHE}_{2}$ induced $\gamma$-H2AX after $1 \mathrm{~h}$ in the presence of Ro 41-0960 (Fig. 1D). On the other hand, all of the treatments induced $\gamma$-H2AX after $12 \mathrm{~h}$, even DMSO (vehicle control) (Fig. 1E).

Generation of the ROS by $2-\mathrm{OHE}_{2}$ or $4-\mathrm{OHE}_{2}$ in the presence or absence of a COMT inhibitor: DCFHDA was used to monitor the accumulation of intracellular ROS. Cells were cultured as described above, and pretreated with $3 \mu \mathrm{M}$ Ro $41-0960$ for $1 \mathrm{~h}$ prior to treatment with $2-\mathrm{OHE}_{2}, 4-\mathrm{OHE}_{2}$ or DMSO as a control for $0-2 \mathrm{~h}$. As shown in Fig. $2 \mathrm{~A}$ and $\mathrm{B}$, an increase in ROS was not observed in the 2-OHE - -treated cells, with or without Ro 41-0960. Likewise, 4-OHE 2 by itself did not 
(A) 2-OHE 2 - COMT inhibitor

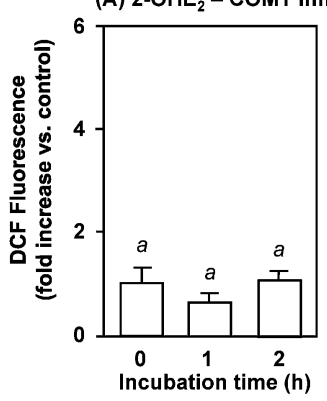

(C) 4-OHE 2 - COMT inhibitor

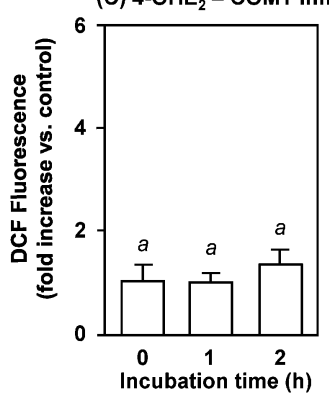

(B) $2-\mathrm{OHE}_{2}+\mathrm{COMT}$ inhibitor

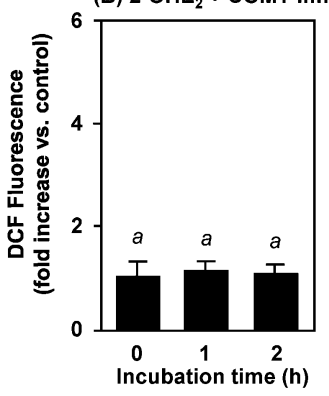

(D) 4-OHE 2 + COMT inhibitor

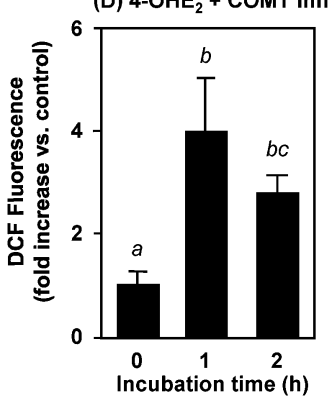

Fig. 2. Generation of ROS in MCF-7 cells treated with or without 2-OHE ${ }_{2}$ and $4-\mathrm{OHE}_{2}$, in the presence or absence of a COMT inhibitor. MCF-7 cells were pretreated with (B and D) or without (A and C) a COMT inhibitor (3 $\mu \mathrm{M}$ Ro 41-0960) for $1 \mathrm{~h}$, and then exposed to 30 $\mu \mathrm{M} 2-\mathrm{OHE}_{2}$ (A and B) or 4-OHE 2 (C and D) for $0-2 \mathrm{~h}$. Next, the cells were loaded with ROS probe DCFH-DA $(5 \mu \mathrm{M})$ for $30 \mathrm{~min}$. Cells were then washed twice with fresh PBS to remove excess DCFH-DA. The cell-associated fluorescence was measured over a $0-2 \mathrm{~h}$ timeframe, with an excitation and emission of $485 \pm 20$ and $530 \pm 25 \mathrm{~nm}$, respectively. Cells treated with $100 \mu \mathrm{M} \mathrm{H}_{2} \mathrm{O}_{2}$ were used as a positive control and non-DCFH-DA-loaded cells were used as a negative control. Data are presented as the relative DCFH fluorescence (fold increase vs negative control) and expressed as the mean $\pm \operatorname{SD}(n=5)$. Different alphabetical superscripts on the top of each column indicate statistically significant differences at $p<0.05$ as evaluated by the Tukey test.

generate the ROS until after $2 \mathrm{~h}$ of exposure (Fig. 2C). However, the cells treated with Ro 41-0960 and 4-OHE 2 $(30 \mu \mathrm{M})$ showed intense fluorescence at both the 1 and $2 \mathrm{~h}$ time points (Fig. 2D). The relative fluorescence of $100 \mu \mathrm{M} \mathrm{H}_{2} \mathrm{O}_{2}$ treatment for $1 \mathrm{~h}$ was $22.9 \pm 6.2$.

Formation of AP sites induced by $2-\mathrm{OHE}_{2}$ or 4-OHE 2 in the presence or absence of a COMT inhibitor: AP sites are common lesions in DNA and are thought to be intermediates in mutagenesis. As shown in Fig. 3A and $\mathrm{B}, 2-\mathrm{OHE}_{2}$ did not form AP sites in the presence or absence of Ro 41-0960 in MCF-7 cells. 4- $\mathrm{OHE}_{2}$ alone also did not form AP sites until after $2 \mathrm{~h}$, but this increase was minimal (Fig. 3C). However, a significant increase in the formation of AP sites was observed in the cells treated with 4-OHE 2 and Ro 41-0960 at both the 1 and $2 \mathrm{~h}$ time points (Fig. 3D).

Inhibition of 4-OHE ${ }_{2}$ and Ro 41-0960-induced $\gamma$ H2AX by ATM inhibitor: The effect of the ATM inhibitor, KU-55933, on $\gamma$-H2AX induction by $4-\mathrm{OHE}_{2}$ and Ro 41-0960 was next examined in MCF-7 cells. The cells

(A) $2-\mathrm{OHE}_{2}-\mathrm{COMT}$ inhibitor

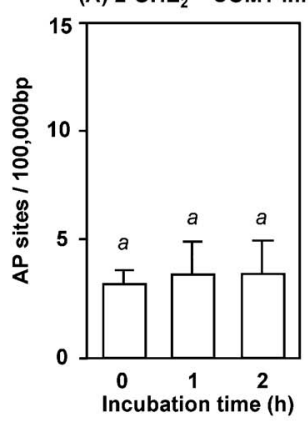

(B) $2-\mathrm{OHE}_{2}+\mathrm{COMT}$ inhibitor

(C) 4-OHE 2 - COMT inhibitor

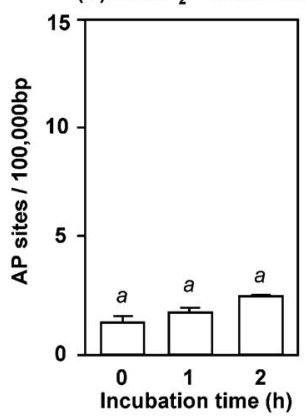

Fig. 3. AP site formation in MCF-7 cells treated with or without a COMT inhibitor, 2-OHE 2 and 4-OHE 2 . MCF-7 cells were pretreated with (B and D) or without (A and C) COMT inhibitor ( $3 \mu \mathrm{M}$ Ro 41-0960) for $1 \mathrm{~h}$, and then exposed to $30 \mu \mathrm{M}$ of $2-\mathrm{OHE}_{2}$ (A and $\mathrm{B}$ ) or $4-\mathrm{OHE}_{2}(\mathrm{C}$ and $\mathrm{D})$ for $0-2 \mathrm{~h}$. Values indicate mean \pm S.D $(n=4)$. Different alphabetical superscripts on the top of each column indicate statistically significant differences at $p<0.05$ as evaluated by the Tukey test.
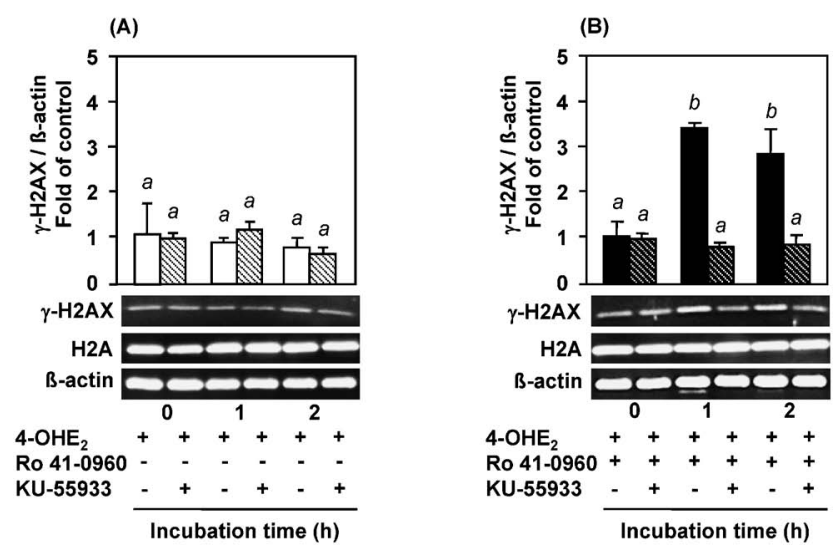

Fig. 4. Effect of ATM inhibitor on $\gamma-\mathrm{H} 2 \mathrm{AX}$ induction by $4-\mathrm{OHE}_{2}$ and a COMT inhibitor, in MCF-7 cells. MCF-7 human breast cancer cells were pretreated with (B) or without (A) COMT inhibitor $(3 \mu \mathrm{M}$ Ro 41-0960) and ATM inhibitor (KU-55933, $10 \mu \mathrm{M}$ ) for $1 \mathrm{~h}$, and then exposed to $30 \mu \mathrm{M} 4-\mathrm{OHE}_{2}$ in the presence or absence of KU-55933 (10 $\mu \mathrm{M})$ for $0-2 \mathrm{~h}$. Values indicate the mean \pm S.D. $(n=5)$. Different alphabetical superscripts on the top of each column indicate statistically significant differences at $p<0.05$ as evaluated by the Tukey test.

were pre-treated with $3 \mu \mathrm{M}$ Ro $41-0960$ or $10 \mu \mathrm{M}$ KU-55933, or both, for $1 \mathrm{~h}$, and then treated with 30 


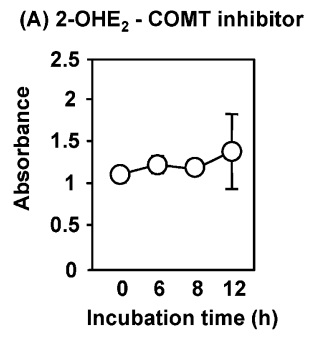

(B) $2-\mathrm{OHE}_{2}+\mathrm{COMT}$ inhibitor

(C) 4-OHE 2 - COMT inhibitor
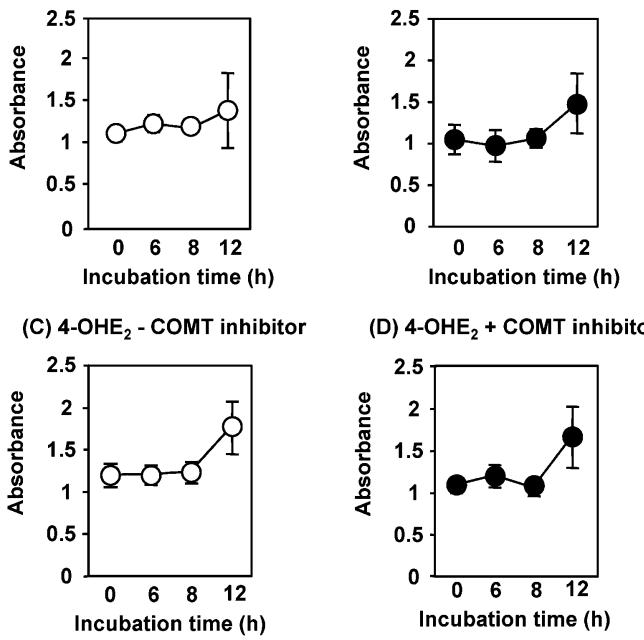

(D) $4-\mathrm{OHE}_{2}+\mathrm{COMT}$ inhibitor

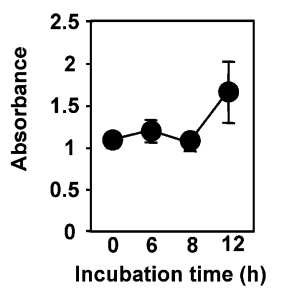

(E) Vehicle control (DMSO)

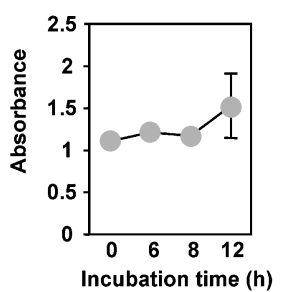

Fig. 5. Proliferation of MCF-7 cells treated with or without a COMT inhibitor, 2-OHE 2 or $4-\mathrm{OHE}_{2}$. MCF-7 human breast cancer cells were pretreated with (B, D and E) or without (A and C) COMT inhibitor (3 $\mu \mathrm{M}$ Ro 41-0960) for $1 \mathrm{~h}$. Cells were then exposed to $30 \mu \mathrm{M}$ $2-\mathrm{OHE}_{2}$ (A and $\left.\mathrm{B}\right), 4-\mathrm{OHE}_{2}$ (C and D) or DMSO (vehicle control (E)) for $0,6,8$ or $12 \mathrm{~h}$ to assess cell viability using the CCK-8 assay.

$\mu \mathrm{M} \mathrm{4-OHE}$ for $0-2 \mathrm{~h}$. As shown in Fig. 4, KU-55933 inhibited $\gamma$-H2AX induction by 4-OHE 2 and Ro 41-0960 at both 1 and $2 \mathrm{~h}$ times points. These results suggest that ATM is the major kinase responsible for the $4-\mathrm{OHE}_{2}$ and Ro 41-0960-induced $\gamma$-H2AX in MCF-7 cells (Fig. 4).

Cell proliferation by $2-\mathrm{OHE}_{2}$ or $4-\mathrm{OHE}_{2}$ in the presence or absence of a COMT inhibitor: Under the cell culture condition of the present study, cell numbers were unchanged until approximately $8 \mathrm{~h}$ for all treatments. Slight, insignificant increases in proliferation were observed after $12 \mathrm{~h}$ for all groups (Fig. 5).

\section{Discussion}

DNA DSBs result from exposure to ionizing radiation or various chemical agents, or even from normal DNA replication. They are regarded as the most lethal type of DNA lesion because damage to both DNA strands prevents using the complimentary DNA strand as a template for DNA repair (26). Phosphorylation of a histone variant, $\mathrm{H} 2 \mathrm{AX}$, is one of the earliest events after DSBs (30). H2AX is phosphorylated at a highly conserved serine 139 residue in the $\mathrm{C}$-terminal tail of this histone. $\gamma$ -
H2AX provides a scaffold for other checkpoint signaling and DNA repair proteins to accumulate in the vicinity of DSBs (31). DNA is wrapped around histone octamers and packaged further into higher order structures. Therefore, during DNA repair, chromatin remodeling is required to relax this tight packaging to allow access of repair proteins to the damaged sites in DNA. After DNA repair is complete, chromatin remodeling complexes then play an important role in restoring normal cell cycle progression (32). Chromatin remodeling functions in all stages of DNA damage response (DDR) in eukaryotic cells. DDR is also involved in the activation of checkpoints that delay progression of the cell cycle, and thus allow time for DNA repair. Activation of the ATM protein is one of the earliest cellular responses to DSBs (33). In undamaged cells, ATM resides as a catalytically inactive dimer or multimer. Upon DNA damage, it is first acetylated by a specific histone acetyltransferase, TIP60 (34), followed by autophosphorylation of Ser1981, which leads to the activation of ATM kinase activity $(33,34)$. 17 $\beta$-estradiol $\left(\mathrm{E}_{2}\right)$-induced DNA DSBs, as determined by the formation of $\gamma-\mathrm{H} 2 \mathrm{AX}$ foci, can be observed by immunofluorescent staining (35). Foci formation has been shown to be dependent upon estrogen receptor- $\alpha(\mathrm{ER} \alpha)$ and the catalytic activity of the type II topoisomerase, topoisomerase IIb (topoIIb) (26). DNA DSBs formed by the strand-cleaving activity of the topoIIb-DNA cleavage complex at estrogen-inducible genes can present a barrier to DNA replication, leading to persistent DNA DSBs in ER $\alpha$-positive breast cancer cells (26). In their study, it was noted that $4-\mathrm{OHE}_{2}$ did not show a significant increase in $\gamma$ - $\mathrm{H} 2 \mathrm{AX}$ foci formation in MCF-7 cells (data not shown). This study sought to investigate whether catechol estrogen metabolites, such as $4-\mathrm{OHE}_{2}$ and $2-\mathrm{OHE}_{2}$, could induce $\gamma-\mathrm{H} 2 \mathrm{AX}$ in the presence or absence of a COMT inhibitor in human breast cancer MCF-7 cells. Catechol estrogens have been implicated in estrogen-induced carcinogenesis. In our study, $2-\mathrm{OHE}_{2}$ did not induce $\gamma-\mathrm{H} 2 \mathrm{AX}$ in the presence or absence of Ro 41-0960. 4-OHE 2 by itself also did not induce $\gamma$-H2AX in the absence of Ro 41-0960 (Fig. 1). These results are consistent with the previous report (26). Only in the presence of Ro 41-0960 did $4-\mathrm{OHE}_{2}$ induce formation of $\gamma$ - $\mathrm{H} 2 \mathrm{AX}$ after 1 and 2 h. Ro 41-0960 inhibits the COMT-directed methylation of catechol estrogens to methoxyestrogens $\left(2-\mathrm{MeOE}_{2}\right.$ and 4- $\mathrm{MeOE}_{2}$ ), which simultaneously increases the potential for DNA damage and decreases the concentration of 2- $\mathrm{MeOE}_{2}$, an anti-proliferative metabolite. $4-\mathrm{OHE}_{2}$, an oxidized metabolite of $\mathrm{E}_{2}$ formed preferentially by cytochrome $\mathrm{P} 450$ 1B1, undergoes 2-electron oxidation to quinone via semiquinone, during which ROS can be generated (36). Here, we showed that $4-\mathrm{OHE}_{2}$ induced ROS after 1 and $2 \mathrm{~h}$ in the presence of 
Ro 41-0960 (Fig. 2). 4-OHE 2 is enzymatically oxidized to $\mathrm{E}_{2}-3,4$-quinones, which have the potential to damage DNA by forming predominantly depurinating adducts, $4-\mathrm{OHE}_{2}-1-\mathrm{N}^{3} \mathrm{Ade}$ and $4-\mathrm{OHE}_{2}-1-\mathrm{N}^{7} \mathrm{Gua}$, leading to premutagenic AP sites, which in turn cause the accumulation of mutations and probably cell transformation (37). We showed that $4-\mathrm{OHE}_{2}$ generated ROS and formed AP sites 1 and $2 \mathrm{~h}$ after Ro 41-0960 treatment (Fig. 3). This consequently induced $\gamma-\mathrm{H} 2 \mathrm{AX}$ in the presence of Ro 41-0960. $\gamma$-H2AX formation is thought to be catalyzed by ATM. We showed that KU-55933, an inhibitor of ATM, suppressed $\gamma$-H2AX in the presence of Ro 41-0960 and 4-OHE (Fig. 4). Collectively, these results suggest that ROS, AP sites and ATM are responsible for $4-\mathrm{OHE}_{2}$ induced $\gamma-\mathrm{H} 2 \mathrm{AX}$ in the presence of Ro 41-0960. Interestingly, we also observed induction of $\gamma$ $\mathrm{H} 2 \mathrm{AX}$ after $12 \mathrm{~h}$ in all treatments (Fig. 1A-E). It has been suggested that $\mathrm{E}_{2}$ induces $\gamma-\mathrm{H} 2 \mathrm{AX}$ in response to DNA replication (26). As shown in Fig. 5, under cell culture condition of this study, the cell numbers were unchanged until after $8 \mathrm{~h}$ in all treatment conditions. However, a slight increase was observed after $12 \mathrm{~h}$. Therefore, this induction of $\gamma-\mathrm{H} 2 \mathrm{AX}$ observed after $12 \mathrm{~h}$ may be responsive to cell cycle-dependent DNA replication. In conclusion, in the present study, we showed that $4-\mathrm{OHE}_{2}$, the potent carcinogenic metabolite, generated ROS and then induced ATM dependent $\gamma$-H2AX formation in response to DNA damage such as AP sites in the presence of a COMT inhibitor. Previous studies have shown that breast cancer tissues have a higher expression of the $\mathrm{E}_{2}$ metabolic activating enzyme, CYP1B1, and a lower expression of the catechol estrogens deactivating enzymes, COMT, as compared with normal breast tissues (13). This in turn causes a higher concentration of $4-\mathrm{OHE}_{2}$ in the breast cancer tissues $(38,39)$. Further, there is an increased rate of cell division in response to DNA replication in breast cancerous cells. Hence, the results of this study suggest that breast cancer tissues will show a high induction of $\gamma$ $\mathrm{H} 2 \mathrm{AX}$. In addition to being widely used for fundamental research in the last decade, $\gamma-\mathrm{H} 2 \mathrm{AX}$ may be identified as a biomarker for breast cancer and use to better understand aging.

Acknowledgements: This work was supported by the Global Center of Excellence (COE) program from the Ministry of Education, Culture, Sports, Science and Technology of Japan. The authors would like to thank Dr. T. Toyooka and Dr. Y. Ibuki (Graduate School of Nutritional and Environmental Sciences, University of Shizuoka) for their kind advice on the detection of $\gamma$ $\mathrm{H} 2 \mathrm{AX}$.

\section{References}

1 Dorgan JF, Stephenson HE Jr, Falk RT, Miller R, Franz
C, et al. Relation of prediagnostic serum estrogen and androgen levels to breast cancer risk. Cancer Epidemiol Biomarkers Prev. 1996; 5: 533-9.

2 Landis SH, Murray T, Bolden S, Wingo PA. Cancer statistics. CA Cancer J Clin. 1999; 49: 8-31.

3 Lalloo F, Varley J, Ellis D, Moran A, Odair L, et al. Prediction of pathogenic mutations in patients with earlyonset breast cancer by family history. Lancet. 2003; 361: $1101-2$.

4 Bernstein L, Ross RK. Endogenous hormones and breast cancer risk. Epidemiol Rev. 1993; 15: 48-65.

5 Kelsey JL, Gammon MD, John EM. Reproductive factors and breast cancer. Epidemiol Rev. 1993; 15: 36-47.

6 Pike MC, Spicer DV, Pahmoush L, Press MF. Estrogens, progestogens, normal breast cell proliferation, and breast cancer risk. Epidemiol Rev. 1993; 15: 17-35.

7 Thomas HV, Key TJ, Allen DS, Moore JW, Dowsett M, Fentiman IS, Wang DY. A prospective study of endogenous serum hormone concentrations and breast cancer risk in postmenopausal women on the island of Guernsey. Br J Cancer. 1997; 76: 401-5.

8 Hankinson SE, Willett WC, Manson JE, Colditz GA, Hunter DJ, et al. Plasma sex steroid hormone levels and risk of breast cancer in postmenopausal women. J Natl Cancer Inst. 1998; 90: 1292-9.

9 Kabuto M, Akiba S, Stevens RG, Neriishi K, Land CE. A prospective study of estradiol and breast cancer in Japanese women. Cancer Epidemiol Biomarkers Prev. 2000; 9: 575-9.

10 Endogenous Hormones and Breast Cancer Collaborative Group. Endogenous sex hormones and breast cancer in postmenopausal women: reanalysis of nine prospective studies. J Natl Cancer Inst. 2002; 94: 606-16.

11 Fernandez SV, Russo IH, Russo V. Estradiol and its metabolites 4-hydroxyestradiol and 2-hydroxyestradiol induce mutations in human breast epithelial cells. Int $\mathrm{J}$ Cancer. 2006; 118: 1862-68.

12 Cavalieri E, Rogan GE. Catechol quinones of estragens in the initiation of breast, prostate, and other human cancers. Ann NY Acad Sci. 2006; 1089: 286-301.

13 Wen W, Ren Z, Shun XO, Cai Q, Ye C, Gao YT, Zheng $\mathrm{W}$. Expression of cytochrome P450 1B1 and catechol- $O$ methyltransferase in breast tissue and their associations with breast cancer risk. Cancer Epidemiol Biomarkers Prev. 2007; 16: 917-20.

14 Liehr JG, Roy D. Free radical generation by redox cycling of estrogens. Free Radic Biol Med. 1990; 8: 415-23.

15 Chakravarti D, Mailander PC, Li KM, Higginbothams S, Zhang HL, et al. Evidence that a burst of DNA depurination in SENCAR mouse skin induces error-prone repair and forms mutations in the H-ras gene. Oncogene. 2001; 20: 7945-53.

16 Li KM, Todorovic R, Devanesan P, Higginbothams S, Kofeler $\mathrm{H}$, et al. Metabolism and DNA binding studies of 4-hydroxyestradiol and estradiol-3,4-quinone in vitro and in female ACI rat mammary gland in vivo. Carcinogenesis. 2004; 25: 289-97.

17 Cavalieri E, Chakravarti D, Guttenplan J, Hart E, Ingle $\mathrm{J}$, et al. Catechol estrogen Quinones as initiators of breast 
and other human cancers: Implications for biomarkers of susceptibility and cancer prevention. Biochim Biophys Acta Rev. 2006; 1766: 63-78.

18 Liehr JG, Fang WF, Sirbasku DA, Ari-Ulubelen A. Carcinogeni-city of catecjolestrogens in Syrian hamsters. J Steroid Biochem. 1986; 24: 353-6.

19 Zahid M, Kohi E, Saeed M, Rogan E, Cavalieri E. The greater reactivity of estradiol-3,4-quinone versus estradiol-2,3-quinone with DNA in the formation of depurinating DNA adducts. Implications fortumorinitiating activity. Chem Res Toxicol. 2005; 19: 164-72.

20 Saeed M, Zahid M, Gunselman SJ, Rogan E, Cavalieri E. Slow loss of deoxyribose from the N7deoxyguanosine adducts of estradiol-3,4-quinone and hexestrol-3',4'-quinone. Implications for mutagenic activity. Steroids. 2005; 70: 29-35.

21 Redon CE, Nakamura AJ, Martin OA, Parekh PR, Weyemi US, Bonner WM. Recent developments in the use of $\gamma-\mathrm{H} 2 \mathrm{AX}$ as a quantitative DNA double-strand break biomarker. Aging. 2011; 3: 168-74.

22 Fernandez-Capetillo O, Celeste A, Nussenzweig A. Focusing on foci: $\mathrm{H} 2 \mathrm{AX}$ and the recruitment of DNA damage response factors. Cell Cycle. 2003; 2: 426-7.

23 Burmas S, Chen BP, Murphy M, Kurimasa A, Chen DJ. ATM phosphorylates histone $\mathrm{H} 2 \mathrm{AX}$ in response to DNA double-strand breaks. J Biol Chem. 2001; 276: 42462-7.

24 Manabu K, Mashino M, Sugasawa J, Koike A. Histone H2AX phosphorylation independent of ATM after X-irradiation in mouse liver and kidney in situ. J Rad Res. 2008; 49: 445-9.

25 Wang H, Wang M, Wang H, Bocker W, Lliakis G. Complex H2AX phosphorylation patterns by multiple kinases including ATM and DNA-PK in human cell exposed to ionzing radiation treated with kinase inhibitors. J Cell Physio. 2003; 202: 492-502.

26 Bonner WM, Redon CE, Dickey JS, Nakamura AJ, Sedelinikova OA, et al. $\gamma-\mathrm{H} 2 \mathrm{AX}$ and cancer. Nat Rev Cancer. 2008; 8: 957-67.

27 Williamson LM, Lees-Miller SP. Estrogen receptor $\alpha$ mediated transcription induces cell cycle dependent DNA double-strand breaks. Carcinogenesis. 2011; 32: 279-85.

28 Zahid M, Saeed M, Gaikwad N, Rogan E, Cavalieri E. Inhibition of catechol- $O$-methyltransferase increases estrogen-DNA adduct formation. Free Radic Biol Med. 2007; 43: 1534-40.

29 Xue L, Yu D, Furusawa Y, Okayasu R, Tong J, et al.
Regulation of ATM in DNA double strand break repair accounts for the radiosensitivity in human cells exposed to high linear energy transfer ionizing radiation. Mutat Res. 2009; 670: 15-23.

30 Rogakou EP, Philch DR, Orr AH, Ivanova VS, Bonner WM. DNA double-stranded breaks induce histone H2AX phosphorylation on serine 139. J Biol Chem. 1998; 273: 5858-68.

31 Paull TT, Rogakou EP, Yamazaki V, Kichgessner CU, Gellert M, Bonner WM. A critical role for histone H2AX in recruitment of repair factors to nuclear foci after DNA damage. Curr Biol. 2000; 10: 886-95.

32 Pusapati RV, Rounbehler RJ, Hong S, Powers JT, Yan $M$, et al. ATM promotes apoptosis and suppresses tumorigenesis in response to Myc. Proc Natl Acad Sci USA. 2006; 103: 1446-51.

33 Bakkenist CJ, Kastan MB. DNA damage activates ATM through intermolecular autophosphorylation and dimer dissociation. Nature. 2003; 421: 499-506.

34 Sun Y, Jiang X, Chen S, Fernandes N, Price BD. A role for the Tip60 histone acetyltransferase in the acetylation and activation of ATM. Proc Natl Acad Sci USA. 2005; 102: 13182-7.

35 Rogakou EP, Boon C, Redon C, Bonner WM. Megabase chromatin domains involved in DNA double-strand breaks in vivo. J Cell Biol. 1999; 146: 905-16.

36 Park SA, Na HK, Kim EH, Cha YN, Surh YJ. 4-Hydroxyestradiol induces anchrage-independent growth of human mammary epithelial cells via activation of $\mathrm{IkB}$ kinase: Potential role of reactive oxygen species. Cancer Res. 2009; 69: 2416-24.

37 Cuendet M, Liu X, Pisha E, Li Y, Yao L, et al. Equine estrogen metabolite 4-hydroxyequilenin induces anchorageindependent growth of human mammary epithelial MCF10A cells: differential gene expression. Cancer Res. 2004; 550: 109-21.

38 Lehmann L, Wagner J. Gene expression of 17beta-estradiol-metabolizing isozymes: comparison of normal human mammary gland to normal human liver and to cultured human breast adenocarcinoma cells. Adv Exp Med Biol. 2008; 617: 617-24.

39 Zhao YN, Zhang N, Chen YC, Fang F, Liu XQ. Relative imbalances in the expression of catechol- $O$-methyltransferase and cytochrome P450 in breast cancer tissue and their association with breast carcinoma. Maturitas. 2012; 7: $5747-54$. 